\title{
Prediction of Marital Adjustment in the Context of Personality Traits, Relationship Beliefs and Conflict Resolution Styles (Sample of Diyarbakır) ${ }^{1}$
}

\author{
DOI: $10.26466 /$ opus. 854688
}

\author{
Özlem Çakmak Tolan* - Mustafa Kılıç** \\ * Dr. Öğr. Üyesi, Dicle Üniversitesi, Diyarbakır/Türkiye \\ E-Mail: ozlemtolan@gmail.com \\ ORCID: $0000-0002-8128-6498$ \\ ** Prof. Dr., Ufuk üniversitesi, İstanbul/Türkiye \\ E-Mail: kilicmustafa49@gmail.com \\ ORCID: 0000-0001-7065-3785
}

\begin{abstract}
In this study, whether there is a significant relationship between the personality traits, relationship beliefs, and conflict-resolution styles and whether there is any significant difference between some demographic variables with respect to marital adjustment were investigated. Additionally, the prediction of marital adjustment regarding personality traits, relationship beliefs, and conflict resolution styles was aimed. The study was conducted with 656 married individuals in total: 292 women and 364 men. Dyadic Adjustment Scale (DAS), Five-Factor Personality Inventory (FFPI), Relationship Beliefs Inventory (RBI), Conflict Resolution Styles Inventory (CRSI), and Personal Information Form were applied to the married couples in the research. The Pearson correlation coefficient methods, one-way ANOVA analysis, and stepwise regression analysis were used to analyze the data obtained. A positive relationship was found between total scores of dyadic adjustments and positive conflict, extraversion, agreeableness, conscientiousness, and openness to experience scales. A negative relationship was found between total scores of dyadic adjustment scale and negative conflict, neuroticism, disagreement is destructive, genders are different and partners don't change subscales. It has been concluded that the marital adjustment of the individuals varies according to their gender, age, number of children, and marriage formation type variables. It has also been found that the strongest variables that predict marital adjustment are neuroticism in terms of personality traits, positive conflict, negative conflict, and withdrawal in terms of conflict-resolution styles, and partners don't change and disagreement is destructive in terms of relationship beliefs. The results obtained were tried to be discussed under the light of the relevant literature.
\end{abstract}

Key Words: Marital adjustment, personality, relationship beliefs, conflict resolution styles.

\footnotetext{
1 This study was produced from the doctoral thesis prepared by Dr. Özlem TOLAN under the advisory of Prof. Dr. Mustafa KILIÇ.
} 


\section{Evlilik Uyumunun Kişilik Özellikleri, İlişkiye Dair İnançlar ve Çatışma Çözüm Stilleri Bağlamında Yordanması (Diyarbakır İli Örneği)}

Öz

Mevcut araştırmada evlilik uyumu ile kişilik özellikleri, ilişkiye dair inançlar ve çatışma çözüm stilleri arasında anlamlı bir ilişki olup olmadığı ve bazı demografik değişkenler arasında evlilik uyumu açısından anlaml düzeyde bir fark olup olmadığ araştırılmıştır. Ayrıca evlilik uyumunun, kişilik özellikleri, ilişkiye dair inançlar ve çatışma çözüm stilleri bağlamında yordanması amaçlanmıştır. Araştırma 292 kadın ve 364 erkek olmak üzere 656 evli birey ile yürütülmüştür. Araştırmaya katılan evli bireylere Çift Uyum Ölçeği (ÇUÖ), Beş Faktör Kişilik Ölçeği (BFKÖ), İlişki İnanç Envanteri (İIE), Çatışma Çözüm Stilleri Ölçeği (ÇÇSÖ) ve Kişisel Bilgi Formu uygulanmıştır. Elde edilen verilerin analizi için, Pearson korelasyon katsayısı, tek yönlü ANOVA ve adımsal regresyon analizi yöntemleri uygulanmıştır. Çift uyumu toplam puanları ile olumlu çatışma, dtşadönüklük, uyumluluk, öz disiplin ve gelişime açıklı boyutları arasında olumlu yönde; olumsuz çatışma, nörotiklik, anlaşmazlik zarar verir, cinsiyetler farklıdır ve eşler değişmez boyutları arasında ise olumsuz yönde anlaml ilişki belirlenmiştir. Evli bireylerin evlilik uyumlarının, cinsiyet, yaş, çocuk sayısı ve evlenme biçimi değiş̧kenlerine göre farklılaştığı sonucuna ulaşılmıştır. Evlilik uyumunu yordayan en güçlü değişkenlerin kişilik özelliklerinden nörotiklik, çatışma çözüm stillerinden olumlu çatışma, olumsuz çatışma ve geri çekilme, ilişkiye dair inançlardan ise, eşler değişmez ve anlaşmazlık zarar verir olduğu bulunmuştur. Elde edilen sonuçlar ilgili alanyazın ışı̆̆ı altında tartışılmaya çalışılmıştır.

Anahtar Kelimeler: Evlilik uyumu, kişilik, ilişki inançları, çatışma çözüm stilleri. 


\section{Introduction}

Although individuals build up various relationships during their development process, marriage is accepted as the most important relationship to have in their lifetime (Gottman, 1993). In this sense, marriage is regarded as an important experience and the essential human relationship to both build family relationships and create future generations (Larson and Holman, 1994). Moreover, a marriage relationship is regarded as the most significant social tradition that is accepted by every community to satisfy our emotional needs (Sharif, Soleimani, Candidate, Mani, and Keshavarzi, 2013).

According to Tutarel-Kışlak (1999), while marital adjustment is seen as a complex notion, couples who are constantly in communication can make a consensus regarding the family and marriage and solve their problems in a positive way have marriage defined as well adjusted marriage. As for Rosen-Grandon, Myers and Hattie (2004), individuals who have a good and well-adjusted marriage feel themselves happier, are healthier in a physical and mental scale, and can lead their life in a more meaningful way. Halford and Markman (1997) define four main features for marital adjustment. These features are related to the positive interactions in a marriage relationship, effective communication and successful conflict management, a positive approach to the partner, and relationship schemes. Within the context of the current research on the factors considered to be related to marital adjustment, it is aimed to examine the relationship between personality traits, beliefs for relationship, and conflict resolution styles.

\section{Marital Adjustment and Personality Traits Relationship}

In the related literature, one of the variables whose relation is examined with marital adjustment is personality traits. Some interpersonal and internal factors affect the marriage relationship. Within this framework, it is stated that the personality is a prominent factor, and it is suggested that individuals have certain stable, steady, and persistent traits (Costa and McCrae, 1992). In this aspect, it is underlined that having certain person- 
ality traits has a powerful effect on both marital adjustment and the conflicts and peace that emerge in relationships. Moreover, it is stated that people inevitably carry their personality traits to their marriage (Craig and Olson 1995; Decuyper, De Bolle, and De Fruyt 2012). According to Lavee and Ben-Ari (2004), personality traits affect how the problems emerge in marriage are perceived, how individuals express their emotions, and how they act in a conflict; and it is shown as the critical factors in a conflict. In a research conducted by Gattis, Berns, Simpson and Christensen (2004), a relationship between a decrease in marital adjustment and high-level neuroticism, low-level reconcilability, and the ability to express less positively has been found. Other research by Karney and Bradbury (1995) found a relationship between neuroticism and negative affection and low marital satisfaction.

Personality traits are commonly evaluated in terms of Five Factors Model (FFM) and considered in five scales. These scales are neuroticism, extroversion, openness to experience, agreeableness, and conscientiousness. The neuroticism scale includes negative emotions such as fear, anger, uneasiness, which is experienced chronically. Extroversion scale is explained by the characteristics such as being energetic, excited, cheerful, talkative, and social. Openness to experience scale involves a high level of imagination, eagerness to learn, having an explorer character, not being traditional, being curious, independent, and creative. Persons who have high agreeableness are defined as being humble, docile, loving, generous, honest, flexible, kind, respected and having a high level of social interest. As for the conscientiousness, it includes characteristics such as control, responsibility, success, competence, and high sense of duty. In research on romantic and marital relationships, the level of neuroticism of individuals is shown as the most consistent and powerful personality predictor. There is a negatively meaningful relationship between neuroticism scale and marital adjustment (Heller, Ilies, and Watson 2004; Kurdek 1995; Karney and Bradbury 1995). Research conducted by Zoby (2005) found a positive relationship between marital adjustment and agreeableness and openness to experience subscales and a negative relationship with neuroticism. Caughlin, Huston, and Houts (2000) examined neuroticism and the observed negative lives of couples in a longitudinal study lasting thirteen years. It is stated that couples with high neuroticism scores have a more 
negative communication pattern, and this situation leads to a toxic effect on relationship satisfaction. According to the extroversion scale, while some research has found a positive relationship between marital satisfaction and extroversion (Hayes and Joseph 2003; Karney and Bradbury 1995), some research shows a negative relationship (Aluja, del Barrio, and García 2007; Kelly and Conley 1987). Research conducted by Akram and Malik (2011) found a positive relationship between marital adjustment and the extroversion and conscientiousness scales.

\section{Marital Adjustment and Irrational Beliefs Relationship}

One of the individual variables whose relationship is examined with marital adjustment is the variable of irrational beliefs, which is covered in the research. According to Ellis (1994), irrational beliefs prevent people from achieving their goals and can cause them to be in trouble and harming themselves or others. In another aspect, irrational beliefs cause people to experience emotions such as anger, depression, anxiety, and guilt more intensely. Most of the research in this context underlines that dysfunctional relationship beliefs have a considerable contribution to marital adjustment (Debord, Romans and Krieshok 1996; Epstein, Pretzer and Fleming 1987). It is stated that irrational beliefs about marital problems are exaggerated, strict, and illogical. Unrealistic or persistent expectations can lead to frustration and tension, along with negative interactions (Digiuseppe and Zee, 1986).

A research conducted by Dowd, Means, Pope and Humphries (2005) found a relationship between low level of negative attributions and increase in marital satisfaction. In research conducted by Addis and Bernard (2002), a relationship between irrational thoughts and marital problems has been detected. Another study by Koolaee, Adibrad and Sedgh (2010) compared the relationship beliefs of 50 women who applied for divorce and 50 women whose marriage continue. According to the research results, it was determined that women who were in the divorce process have more irrational beliefs and these differences are seen in the subscales of "spouses cannot be changed" and "disagreement is destructive". 


\section{Marital Adjustment and Conflict-Resolution Styles Relationship}

One of the variables examined under the current research is conflict-resolution styles. In recent research on marital adjustment, it is seen to be focused on interpersonal variables such as communication, problem solving, conflict-resolution styles. Prado and Markman (1999) suggest that how couples manage their conflicts is more related to marital adjustment or divorce than the number and content of the problems happen in marriage. According to Greeff and De Bruyne (2000), when marital conflicts are managed constructively, relationships are stronger, and when it is managed destructively, the possibility of unsatisfied and unhappy relationships incases. Heavey, Layne and Christensen (1993) and Metz and Dwyer (1993) suggest that conflict management is one of the most important determinants that has a strong effect on well-being and marital satisfaction in relationships.

Conflict-resolution styles used in marital relationships are addressed by different researchers. According to Burman, Margolin and John (1993), couples have three conflict-resolution styles. These are physical aggressiveness, verbal aggressiveness, and withdrawal. According to Greef and Bruyne (2000), conflicts are defined as constructive and destructive. Constructive conflict is defined as a conflict style that includes components such as being relationship-oriented instead of being flexible and individual-oriented. A study by Stanley, Markman and Whitton (2002) found a relationship between negative communication and interaction between spouses and increase of divorce potential. Withdrawal conflict-resolution style is determined to be widely used, and that increases the negativity in relationships and decreases the positive relationship. In a study conducted by Dwyer (2005), emotional intelligence and dysfunctional conflict-resolution style have been found to be predictor variables of marital dissatisfaction. Positive problem solving, withdrawal, and adaptation conflictresolution styles are found not being predictor variables of marital unsatisfaction.

Today, studying marital relationships is of big importance in terms of both theoretical and clinical purposes. Snyder, Heyman and Haynes (2005) state that only a third of married people feel happy in their marriage. Bradbury et. (2000) emphasized that problems in marriage can cause 
negative situations such as increased symptoms of anxiety and depression of individuals and psychological problems of children. It is considered that it is very important to determine the variables affecting marital adjustment by considering the increasing rate of divorce, marital adjustment, and mental-physical health, raising healthy children, and protecting public mental health in a broader term. In this context, a better understanding of conflict-resolution styles, personality traits, relationship beliefs, and marital adjustment will contribute to the literature and field applications about marriage.

Research questions built regarding the overall purpose of the research are listed below.

- Is there a meaningful relationship between personality traits, beliefs in relationship, conflict-resolution styles, and marital adjustment?

- Is there a significant difference in demographic difference variables such as gender, age difference between couples, marriage formation type, number of children in terms of marital adjustment?

- Do personal traits predict marital adjustment at a meaningful level?

- Do beliefs in relationships predict marital adjustment at a meaningful level?

- Does conflict-resolution styles predict marital adjustment at a meaningful level?

\section{Research Model}

This research is descriptive research that examines the current situation. The main objective of this research is to analyze married individuals' personality traits, beliefs on relationship, and conflict-resolution styles based on the variables considered to affect marital adjustment. The dependent variable of this research is marital adjustment, and the predictor variables are personality traits, beliefs in relationship, and conflict-resolution styles.

\section{Study Group}

The population of this research consists of married couples who live in the city center of Diyarbakır and has spent at least one year in their marriage. As for the study group of this research, they consist of married individuals 
who work in various institutions in Diyarbakır city center and have spent at least one year in their marriage. In this research, convenience sampling method was used to determine the study group. Convenience sampling method is to select the sample from easily accessible and applicable units due to the existing limits in terms of time, money, and labor (Fraenkel and Wallen, 1993). Research participation was provided on a voluntary basis.

Demographic information about the study group is given in Table 1.

Table 1. Demographic Information of the Married Individual Participants

\begin{tabular}{|c|c|c|c|}
\hline & & $\mathrm{n}$ & $\%$ \\
\hline \multirow[t]{3}{*}{ Gender } & Women & 292 & 44.5 \\
\hline & Men & 364 & 55.5 \\
\hline & Total & 656 & 100 \\
\hline \multirow[t]{4}{*}{ Age } & $21-30$ & 141 & 21.5 \\
\hline & $31-40$ & 328 & 50 \\
\hline & 41 and above & 187 & 28.5 \\
\hline & Total & 656 & 100 \\
\hline \multirow[t]{5}{*}{ Education Level } & Primary/Secondary & 40 & 6.1 \\
\hline & High School & 148 & 22.6 \\
\hline & Associate degree & 227 & 34.6 \\
\hline & Undergraduate and Graduate & 241 & 36.7 \\
\hline & Total & 656 & 100 \\
\hline \multirow[t]{5}{*}{ Number of Children } & None & 101 & 15.4 \\
\hline & Only child & 186 & 28.4 \\
\hline & Two children & 216 & 32.9 \\
\hline & Three children and more & 153 & 23.3 \\
\hline & Total & 656 & 100 \\
\hline \multirow[t]{3}{*}{ Marriage formation type } & Dating & 482 & 73.5 \\
\hline & Arranged marriage & 174 & 26.5 \\
\hline & Total & 656 & 100 \\
\hline \multirow[t]{3}{*}{ Age Gap Between Spouses } & $0-5$ years & 484 & 73.8 \\
\hline & Six years and above & 172 & 26.2 \\
\hline & Total & 656 & 100 \\
\hline Degree of Kinship Between & Kin & 138 & 21 \\
\hline \multirow[t]{2}{*}{ Spouses } & Non-kin & 518 & 79 \\
\hline & Total & 656 & 100 \\
\hline \multirow[t]{6}{*}{ Income Level } & $500-1000 \mathrm{TL}$ & 42 & 6.4 \\
\hline & $1001-2000 \mathrm{TL}$ & 98 & 14.9 \\
\hline & 2001-3000 TL & 134 & 20.4 \\
\hline & 3001-4000 TL & 113 & 17.2 \\
\hline & $4001-5000$ & 141 & 21.5 \\
\hline & $5001 \mathrm{TL}$ and above & 128 & 19.5 \\
\hline Total & Total & 656 & 100 \\
\hline
\end{tabular}




\section{Data Collection Tools}

Personal Information Form: A Personal Information Form made by the researcher was used to determine the participants' demographic information such as gender, age, marriage age, and level of education.

Dyadic Adjustment Scale (DAS): In this study, Dyadic Adjustment Scale (DAS) was used to determine marital adjustment levels of married individuals. In the standardization research carried out by Fişıloğlu and Demir (2000) in our country, it was stated that this scale is a reliable and valid scale for the samples in Turkey. Cronbach value obtained in total points from the scale is 0.92 , for the happiness of the couple .83; for the couple's devotion .75; for the couple's co-decision .75; for the emotional expression 80 is found. Within the scope of the current research, Cronbach alpha reliability parameter is found to be .93 out of the total point of the scale.

Five Factor Personality Inventory (FFPI): The Five Factor Personality Inventory was developed by Benet-Martinez and John (1998) as "The Big Five Inventory" and consists of 44 items. Prepared briefly in terms of effective and rapid evaluations of researchers, this scale measures the dimensions of "neuroticism", "extroversion", "openness to experience", "agreeableness" and " conscientiousness " from personality traits. The Turkish adaptation of the inventory was made by Sümer (2005), and other research stated that Cronbach alpha reliability values of the five-factor personality scales vary between .64 and.77 (Sumerian, Lajunen and Özkan, 2005). Within the scope of the current research, Cronbach alpha reliability coefficients for the lower subscales were found to be .65 for neuroticism subscale; .68 for extroversion subscale; .55 for agreeableness subscale, .68 for the conscientiousness subscale, and .72 for the openness to experience subscale. Cronbach alpha reliability coefficient made on the total score is found as .74

Relationship Belief Inventory: It is an inventory of a total of 40 items by Eidelson and Epstein (1982) to assess dysfunctional beliefs in close rela- 
tionships. It is stated that the RBI consists of five sub-scales called "Disagreement is destructive to a relationship", "Partners should be able to mindread", "Partners don't change", "One should be sexually perfect" and "There are dramatic differences between men's and women's personality and needs". In their study, Kapci, and Turkçapar (2010) found that all items were included in accordance with the recommended five-factor structure. Cronbach alpha reliability coefficients made for the lower subscales under the current research were found to be .70 for " Disagreement is destructive " sub-scale, .62 for "genders are different" sub-scale, .57 for the "Partners should be able to mindread" sub-scale, .60 for the "Sexual perfectionism " sub-scale, and .58 for the "Partners don't change" subscale. Cronbach alpha reliability coefficient made on the total score is found as .72.

Conflict-Resolution Styles Inventory: Conflict Resolution Styles Inventory (CRSI) was developed by Özen (2006) to measure couples' conflict resolution styles. The inventory measures four conflict resolution styles: positive, negative, compliance, and withdrawal conflict resolution styles. Cronbach alpha internal consistency coefficients for positive, negative, withdrawal, and compliance sub-scales of conflict-resolution styles scale were calculated as .77, .81, .75 and .80, respectively. Cronbach alpha internal consistency coefficients made for the lower subscales under the current research were found to be 72 for the "Positive Conflict Solving Style" sub-scale, .81 for the "Negative Conflict Solving Style" sub-scale, .69 for the "Withdrawal Conflict Solving Style" sub-scale, .68 for the "Compliance Conflict Solving Style" sub-scale, and .93 for the total score.

\section{Data Analysis}

As a result of the application, the data of 14 people who filled in incorrectly or incompletely and 47 people because of the extreme value analyses were not analyzed. The data of the remaining 656 people were analyzed. The SPSS-21 package program was used in the data analysis. In accordance with the initial objective of the research, to determine relationships between variables, correlation analysis; to determine the strength of 
each of the independent variables in predicting couple adjustments, stepwise regression analysis was used. To determine whether the data showed normal distribution, Mahalanobis and Durbin Watson values which are hypothetical criteria in stepwise regression analysis were considered. It was found that Mahalanobis value was below 25, Durbin Watson values were valued between 1.5 and 2.5 and data showed normal distribution. Correlation values were below .70 among the variables included in the model and there was no multicollinearity problem. It is stated in the regression analysis that the number of participants should be $50+8 \mathrm{k}$ ( $k=$ number of variables) times that of each argument (Field, 2009). 656 individuals participated in the study and it was observed that the criteria for the number of participants were achieved. For the second purpose of the research, t-test and one-way analysis of variance (ANOVA) were applied to the data to determine whether the couple adjustment levels of married individuals varied in terms of gender, age, education level, number of children, marriage formation type, age gap between spouses, degree of kinship between spouses and income level variables. To determine the inter-group differentiation, F statistics; in cases where group variants were evenly distributed for multiple comparisons, "Tukeytest"; and in cases where group variants were not evenly distributed, Dunnet-C" test was used.

In the data analysis, the effect size values showing how effective the independent variables on the dependent variable were also examined. Cohen's $\mathrm{d}$ formula was used to calculate the effect size for statistical methods in which the difference between the averages of the two groups was calculated. As a result of the calculations, Cohen's d value obtained was $<.20$ small; $.20<.50$ medium and $.50<.80$ were interpreted as big effect sizes. Omega square $(\Omega 2)$ method was used to calculate the impact size in comparing more than two groups. Impact sizes for omega square should be interpreted as .01 small, .06 medium, .14 big effect (Kirk, 1996; Field 2009).

\section{Findings}

\section{Descriptive Statistics}

Descriptive statistics of the research scale are given in Table 2. 
Table 2. Descriptive Statistics

\begin{tabular}{llllllll}
\hline Subscales & Scales & $\overline{\boldsymbol{x}}$ & Ss & Min & Max & Skewness & Kurtosis \\
\hline 1- Dyadic adjustment & (DAS) & 107. & 19.51 & 46.00 & 150.00 & -.641 & .273 \\
2- Positive conflict & (CRSI) & 4.41 & .77 & 2.33 & 6.00 & -.317 & -.308 \\
3- Negative conflict & (CRSI) & 2.41 & .88 & 1.00 & 4.86 & .293 & -.542 \\
4-Compliance & (CRSI) & 3.91 & .96 & 1.33 & 6.00 & -.226 & -.281 \\
5- Withdrawal & (CRSI) & 3.85 & .98 & 1.17 & 6.00 & -.205 & -.284 \\
6- Extraversion & (FFPI) & 3.39 & .61 & 1.75 & 5.00 & -.102 & -.238 \\
7- Agreeableness & (FFPI) & 3.97 & .49 & 2.67 & 5.00 & -.329 & -.228 \\
8- Conscientiousness & (FFPI) & 3.87 & .58 & 2.22 & 5.00 & -.318 & -.423 \\
9- Neuroticism & (FFPI) & 2.98 & .62 & 1.50 & 5.00 & .328 & -.068 \\
10- Openness to experience & (FFPI) & 3.50 & .57 & 1.90 & 5.00 & .050 & -.302 \\
11- Disagreement is destructive & (RBI) & 2.04 & .97 & .00 & 4.67 & .119 & -.434 \\
12- Genders are different & (RBI) & 2.92 & .95 & .40 & 5.00 & -.130 & -.297 \\
13- Partners should be able to & (RBI) & 3.16 & .92 & .75 & 5.00 & -.147 & -.313 \\
mindread & & & & & & & \\
14- Sexual perfectionism & $($ RBI) & 2.46 & .93 & .00 & 5.00 & -.074 & .115 \\
15- Partners don't change & (RBI) & 1.52 & .87 & .00 & 4.00 & .372 & .114 \\
\hline
\end{tabular}

Pearson correlation coefficient between the examined variables are given in Table 3.

A positive relationship is found between the total dyadic adjustment total scores of the married individuals that participated in the study, and the subscale scores of the FFPI in conscientiousness, openness to experience, agreeableness, extraversion, and a negative relationship is found with neuroticism $(\mathrm{p}<.01)$. In this context, it is observed that as the marital adjustment degrees increase, conscientiousness, openness to growth, agreeableness, and extraversion in the personality of the married individuals increase. On the other hand, it is concluded that married individuals' increased neuroticism characteristics lead to decreased marital adjustment degrees.

\section{Correlation Analysis}

A negative relationship is found between the total dyadic adjustment scores of the married individuals that participated in the study, and their subscale scores of RBI in disagreement are destructive to a relationship, there are dramatic differences between men's and women's personality and needs, partners cannot change themselves. In this context, it is shown 
that the increase in the beliefs of disagreement is destructive to a relationship; there are dramatic differences between men's and women's personality and needs, and partners cannot change themselves subscales lead to a decrease in marital adjustment. On the other hand, no relationship is found between the partners should be able to mindread, and one should be sexually perfect subscales of the RBI and the total scores of the dyadic adjustment.

Table 3. Pearson Correlation Coefficient Results Among the DAS, CRSI, FFPI AND RBI Scores

\begin{tabular}{|c|c|c|c|c|c|c|c|c|c|c|c|c|c|}
\hline & 1 & 2 & 3 & 4 & 5 & 6 & 7 & 8 & 9 & 11 & 12 & 13 & $14 \quad 15$ \\
\hline 1-Dyadic adjustment & 1 & & & & & & & & & & & & \\
\hline 2-Positive conflict & $.19^{* *}$ & 1 & & & & & & & & & & & \\
\hline 3-Negative conflict & $-.36^{* *}$ & -.07 & 1 & & & & & & & & & & \\
\hline 4-Compliance & .06 & $.23^{* *}$ & $-.18^{* *}$ & & & & & & & & & & \\
\hline 5-Withdrawal & -.06 & $.20^{* *}$ & -.07 & $.40^{* *}$ & 1 & & & & & & & & \\
\hline 6-Extraversion & $.12^{* *}$ & $.12^{* *}$ & -.03 & -.07 & .03 & 1 & & & & & & & \\
\hline 7-Agreeableness & $.15^{* *}$ & $.19^{* *}$ & $-.23^{* *}$ & $.17^{* *}$ & $.10^{*}$ & $.12^{* *}$ & 1 & & & & & & \\
\hline 8-Conscientiousness & $.21^{* *}$ & $.17^{* *}$ & $-.21^{* *}$ & $.09^{*}$ & .07 & $.26^{* *}$ & $.39 * *$ & 1 & & & & & \\
\hline 9-Neuroticism & $-.26^{* *}$ & -.04 & $.31^{* *}$ & $-.09^{*}$ & -.03 & $-.16^{* *}$ & $-.15^{* *}$ & $*-.22^{* *}$ & $* 1$ & & & & \\
\hline 10-Opennes to experience & $.15^{* *}$ & $.19^{* *}$ & $-.16^{* *}$ & ${ }^{*} .04$ & .05 & $.41^{* *}$ & $.26^{* *}$ & $.37^{* *}$ & $-.13^{* *}$ & $* 1$ & & & \\
\hline $\begin{array}{l}\text { 11-Disagreement is de- } \\
\text { structive }\end{array}$ & $-.25^{* *}$ & -.07 & $.33^{* *}$ & -.02 & .02 & $-.08^{*}$ & $-.13^{* *}$ & $*-.09^{*}$ & $.18^{* *}$ & $-.16^{* *} 1$ & & & \\
\hline 12-Genders are different & $-.18^{* *}$ & -.03 & $.21^{* *}$ & .02 & $.09^{*}$ & -.07 & $-.09^{*}$ & -.02 & $.19^{* *}$ & $-.09^{*} .43^{* *}$ & 1 & & \\
\hline $\begin{array}{l}\text { 13-Partners should be able } \\
\text { to min }\end{array}$ & -.04 & $.09^{*}$ & $.11^{* *}$ & .07 & $.12^{* *}$ & .02 & .00 & $.08^{*}$ & $.09^{*}$ & $-.02 \quad .38^{* *}$ & $.41^{* *}$ & 1 & \\
\hline 14-Sexual perfectionism & -.01 & -.03 & .01 & $.14^{* *}$ & .02 & -.05 & -.00 & .03 & -.01 & $-.02 .18^{* *}$ & $.08^{*}$ & $.08^{*}$ & 1 \\
\hline $\begin{array}{l}\text { 15-Partners don't change } \\
\text { themseves }\end{array}$ & $-.27^{* *}$ & $-.17^{* *}$ & $* .15^{* *}$ & $-.15^{* *}$ & $*-.18^{* *}$ & $-.08^{*}$ & $-.12^{* *}$ & $*-.15^{* *}$ & $\star .06$ & $-.10^{* *} .00$ & $-.09^{*}$ & $-.28^{* *}$ & -.061 \\
\hline
\end{tabular}

A positive relationship is found between the total dyadic adjustment scores of the married individuals that participated in the study and the scores they received from the positive conflict subscale of the CRSI, and a negative relationship is found with the negative conflict subscale of the CRSI. In this case, it can be concluded that the use of a positive conflict resolution style, which is one of the conflict resolutions styles of married individuals, increases their marital adjustment level, whereas using a negative conflict resolution style decreases their marital adjustment level. On the other hand, no relationship is found between the total scores of dyadic adjustments obtained from the DAS and the compliance and withdrawal subscales of the CRSI of the married individuals that participated in the study. 


\section{t-test}

Table 4. Marital Adjustmēnt of the Married Individuals by Gender Variable

\begin{tabular}{llllllll}
\hline Gender & $\mathrm{n}$ & $\overline{\boldsymbol{x}}$ & $\mathrm{Ss}$ & $\mathrm{Sd}$ & $\mathrm{t}$ & $\mathrm{p}$ & Cohen's d \\
\hline W o m e n & 292 & 111.40 & 18,81 & & & & \\
M e n & 364 & 104.81 & 19.59 & 654 & 4.35 & $.000^{*}$ & .34 \\
\hline
\end{tabular}

${ }^{*} p<.001$

Whether the marital adjustment scores of married individuals differ according to the gender variable was tested with the t-test. As it is seen in Table 4, marital adjustment $[\mathrm{t}(654)=4.35 ; \mathrm{p}<.01]$ by gender shows a significant difference. It was determined that women have more marital adjustment than men.

\section{One-way analysis of variance}

Table 5. Marital Adjustment of the Married Individuals by Age Variable

\begin{tabular}{llrlllll}
\hline Age & $n$ & $\overline{\boldsymbol{x}}$ & Ss & $F$ & $p$ & Fark & Omega squared $\left(\omega^{2}\right)$ \\
\hline $21-30$ & 141 & 113.79 & 18.16 & & & & \\
$31-40$ & 328 & 105.36 & 19.86 & & & $1-2^{* *}$ & \\
41 and above & 187 & 107.36 & 19.00 & 9.49 & .000 & $1-3^{*}$ & .02 \\
\hline${ }^{*} p<0.5$ & & & & & &
\end{tabular}

Whether the marital adjustment scores of married individuals differ according to the age variable was tested by one-way ANOVA. As seen in Table 5, marital adjustment $[\mathrm{F}(2,653)=9.49$; $\mathrm{p}<.01]$ shows a significant difference in terms of the age variable. Younger married individuals consider their marriages more adjusted than older married individuals.

\section{One-way analysis of variance}

Table 6. Marital Adjustment of the Married Individuals by Education Level Variable

\begin{tabular}{|c|c|c|c|c|c|}
\hline Education Level & $n$ & $\bar{x}$ & Ss & $F$ & $p$ \\
\hline Primary/Secondary/Highschool & 40 & 105.82 & 21.23 & & \\
\hline \multirow[t]{3}{*}{ Assoc./Undergrad./Grad. } & 148 & 107.19 & 20.93 & .362 & .780 \\
\hline & 227 & 107.46 & 19.83 & & \\
\hline & 241 & 108.66 & 18.05 & & \\
\hline
\end{tabular}

${ }^{*} p<0.5$ 
Whether the marital adjustment scores of married individuals differ according to the education level variable was tested by one-way ANOVA. As seen in Table 6, the average score of marital adjustment of married individuals $[F(3,652)=0.362 ; p>.05]$ does not show a significant difference in terms of education level variable.

\section{One-way analysis of variance}

Table 7. Marital Adjustment of the Married Individuals by Number of Children Variable

\begin{tabular}{llrlllll}
\hline Number of Children & $n$ & $\overline{\boldsymbol{x}}$ & Ss & $\boldsymbol{F}$ & $\boldsymbol{p}$ & Difference & $\begin{array}{l}\text { Omega } \\
\text { squared }\left(\omega^{2}\right)\end{array}$ \\
\hline None & 101 & 112.89 & 15.31 & & & & \\
$\quad$ Only Child & 186 & 109.36 & 19.11 & & & $1-3^{*}$ & \\
$2 \quad$ Children & 216 & 103.93 & 20.94 & $6.017^{*}$ & .000 & $2-3^{*}$ & .02 \\
3 Children and more & 153 & 107.75 & 19.50 & & & & \\
\hline${ }^{*} p<0.5$ & & & & & & &
\end{tabular}

Whether the marital adjustment scores of married individuals differ according to the number of children variable was tested by one-way ANOVA. As seen in Table 7, marital adjustment $[\mathrm{F}(3,652)=6.017 ; \mathrm{p}<.01]$ shows a significant difference in terms of the number of children variable. Married individuals who have no child or have only one child experience more marital adjustment than married individuals with two children.

\section{t-test}

Table 8. Marital Adjustment of the Married Individuals by Marriage Formation Type Variable

\begin{tabular}{lrrlllll}
\hline $\begin{array}{l}\text { Marriage Formationn } \\
\text { Type }\end{array}$ & $\bar{x}$ & Ss & sd & $t$ & $p$ & Cohen's $d$ \\
\hline D a ting & 482 & 108.91 & 18.78 & & & & \\
Arranged Marriage & 174 & 104.52 & 104.52 & 654 & $2.413^{*}$ & .016 & .22 \\
\hline${ }^{*} p<0.5$ & & & & & & &
\end{tabular}

Whether the marital adjustment scores of married individuals differ according to the variable of marriage formation type was tested with the $\mathrm{t}$-test. As seen in Table 8, marital adjustment $[\mathrm{t}(654)=4.35 ; \mathrm{p}<.05]$ shows 
a significant difference according to the variable of marriage formation type.

\section{Regression Analysis}

Stepwise Regression Analysis Results on Relationship Beliefs, Conflict Resolution Styles and the Personality Traits in the Prediction of Marital Adjustment

Table 8. Step-By-Step Regression Analysis Results Related to the Prediction of Independent Variables on Marital Adjustment

\begin{tabular}{llllllll}
\hline Analysis Stage & $\mathbf{B}$ & $\begin{array}{l}\text { Standard } \\
\text { Error }\end{array}$ & $\boldsymbol{\beta}$ & $\mathbf{R}$ & $\mathbf{R}^{\mathbf{2}}$ & $\mathbf{t}$ & Sig. \\
\hline 1 (Constant) & 126.66 & 2.06 & & & & 61.21 & .000 \\
Negative conflict & -7.82 & .80 & -.35 & .35 & .12 & -9.737 & .000 \\
\hline 2(Constant) & 132.41 & 2.22 & & & & 59.59 & .000 \\
Negative conflict & -7.10 & .79 & -.32 & .41 & .17 & -8.98 & .000 \\
Partners don't change & -4.92 & .80 & -.22 & & & -6.12 & .000 \\
\hline 3(Constant) & 144.78 & 3.55 & & & & 40.70 & .000 \\
Negative conflict & -5.98 & .82 & -.27 & & & -7.30 & .000 \\
Partners don't change & -4.88 & .79 & -.21 & .44 & .19 & -6.15 & .000 \\
Neuroticism & -5.08 & 1.15 & -.16 & & & -4.41 & .000 \\
\hline 4 (Constant) & 147.47 & 3.57 & & & & 41.22 & .000 \\
Negative conflict & 4.96 & .84 & -.22 & & & -5.85 & .000 \\
Partners don't change & -5.05 & .78 & -.22 & .46 & .21 & -6.44 & .000 \\
Neuroticism & -4.66 & 1.14 & -.15 & & & -4.08 & .000 \\
Disagreement is destructive -3.00 & .74 & -.15 & & & -4.06 & .000 \\
\hline 5 Constant) & 132.66 & 5.54 & & & & 23.92 & .000 \\
Negative conflict & -4.91 & .84 & -.22 & & & -5.84 & .000 \\
Partners don't change & -4.60 & .78 & -.20 & & & -5.83 & .000 \\
Neuroticism & -4.59 & 1.13 & -.14 & .48 & .23 & -4.05 & .000 \\
Disagreement is destructive-2.85 & .73 & -.14 & & & -3.87 & .000 \\
Positive conflict & 3.05 & .87 & .12 & & & 3.47 & .001 \\
\hline 6 Constant) & 141.97 & 5.91 & & & & 24.01 & .000 \\
Negative conflict & -5.09 & .83 & -.23 & & & -6.12 & .000 \\
Partners don't change & -5.05 & .78 & -.22 & & & -6.42 & .000 \\
Neuroticism & -4.63 & 1.11 & -.14 & .50 & .25 & -4.14 & .000 \\
Disagreement is destructive -2.69 & .72 & -.13 & & & -3.70 & .000 \\
Positive conflict & 3.69 & .88 & .14 & & & 4.19 & .000 \\
Withdrawal & -2.91 & .69 & -.14 & & & -4.17 & .000 \\
& & & & & & & \\
\hline
\end{tabular}


As $R^{2}$ values are examined in Table 8 ; it is seen that negative conflict, from the variables that predict marital adjustment, explains $12 \%$ of the total variance $[\mathrm{F}(1,654)=94.80 ; \mathrm{p}<.01]$. In the second phase, the total variance rose to $17 \%[\mathrm{~F}(2,653)=68.80 ; \mathrm{p}<.01]$ as the partners cannot change themselves sub-scale is added; in the third phase it went up to $19 \% \mathrm{~F}(3,652)=$ 53.67; $\mathrm{p}<.01$ ] with the neuroticism sub-scale; in the fourth phase it increased to $21 \%[\mathrm{~F}(4,651)=45.33 ; \mathrm{p}<.01]$ with the disagreement is destructive to a relationship sub-scale; in the fifth phase it inclined to $23 \%$ $[\mathrm{F}(5,650)=39.29 ; \mathrm{p}<.01]$ with the positive conflict scale; and finally, in the sixth phase, it rose to $25 \%[\mathrm{~F}(6,649)=36.47 ; \mathrm{p}<.01]$ with the withdrawal sub-scale.

\section{Discussion and Result}

Discussion and interpretation of the findings of the relations between the marital adjustment and personality traits, relationship beliefs, and conflict resolution styles.

According to the current study results, a positive relationship is found between marital adjustment and positive conflict, extraversion, agreeableness, conscientiousness, and openness to experience. Whereas a negative relationship is found between the marital adjustment and the negative conflict, neuroticism, disagreement is destructive to a relationship, there are dramatic differences between men's and women's personality and needs, and partners cannot change themselves scales.

According to the current study results, a positive relationship is found between the agreeableness subscale and marital adjustment. The result is consistent with the relevant studies in the literature (Botwin, Buss and Shackelford 1997; Russell and Wells 1994). Caughlin, Huston and Houts (2000) indicate that in interpersonal interactions, agreeable individuals are more able to regulate their emotions and engage in interpersonal interactions more softly. Tobin, Graziano, Vanman and Tassinary (2000) indicate that marital adjustment is a significant predictive variable of agreeableness on interpersonal interactions. It is stated that the listening skills of the 
agreeable individuals, their tolerant approach to different perspectives, their successful communication styles, and their low tendency to behave provocatively and aggressively lead to increased marital adjustment.

According to the research findings, a positive relationship is found between the sub-scales of openness to experience and marital adjustment. The result is consistent with the relevant studies in the literature (Donnellan, Conger and Bryant 2004; Russell and Wells 1994). It is indicated that spouses with advanced openness to experience contribute to increased marital adjustment by possessing stronger problem-solving skills, having more flexible attitudes towards experienced changes, and having more willingness to analyze their relationships (Robins, Caspi and Moffitt, 2000).

According to the research findings, a positive relationship is found between the Conscientiousness sub-scale and marital adjustment. The result is consistent with the relevant studies in the literature (Donnellan, Conger and Bryant, 2004). Robins, Caspi and Moffitt (2000) indicate the decrease in the amount and frequency of negative interactions in marriage by emphasizing the less critical behaviors of the individuals with high levels of conscientiousness towards their spouses. It is stated that the marital adjustment increase, and the areas of problems in couple relationships decrease since the individuals with high levels of conscientiousness are responsible, trustworthy, and hardworking.

According to the research findings, a positive relationship is found between the extraversion sub-scale and marital adjustment. In this context, it is seen that different results were obtained in the related studies in the literature. In some studies, a positive relationship (Hayes and Joseph, 2003; Watson, Hubbard and Wiese, 2000), in some studies, a negative relationship (Botwin, Buss and Shackelford, 1997; Gattis, Simpson, Christensen and Berns, 2004) is found between the extraversion scale and marital adjustment. According to Watson, Hubbard and Wiese (2000), extroverted individuals have a positive, outgoing, sympathetic, and cheerful nature. It is indicated that extroverted individuals' compassionate and warm behaviors towards their spouses cause less relationship conflict; thus, marital adjustment increases.

A negative relationship is found between marital adjustment and neuroticism sub-scale. The findings are consistent with the related studies in 
the literature (Buss, 1991; Geist and Gilbert, 1996; Kurdek, 1997; Caughlin, Huston and Houts, 2000). It is claimed that the neuroticism level (negative sensation and emotional inconsistency) is the most predictive variable that has a strong and consistent effect on relationship results (Buss, 1991; Geist and Gilbert, 1996). It is stated that the chronic negative emotions of individuals with high levels of neuroticism affect their marital adjustment. According to Bouchard, Lussier and Sabourin (1999), characteristics such as anxiety, restlessness, and emotional inconsistency of individuals with high neuroticism levels impact decreased marital adjustment.

As stated in the results, it is seen that the use of a positive conflict resolution style leads to increased marital adjustment. The result is consistent with related studies in the literature (Cohan and Bradbury, 1997; Gottman and Krokoff, 1989; Kurdek, 1995). The positive conflict resolution style includes dealing with the conflict using constructive methods such as discussing the conflict situation and finding reasonable solutions for the couples. According to Gottman (1993), handling the conflict positively and constructively increases marital adjustment and relationship stability. Besides, it is stated that the use of reconciliation and negotiation skills in a positive conflict resolution style impacts the rise of marital adjustment. In these marriages, spouses take care of each other, have activities they share, listen to each other, and agree on fundamental values. It is indicated that all the above-mentioned behaviors reveal positive conflict resolution styles and increase the dyadic adjustment.

According to the research findings, a negative relationship is found between marital adjustment and negative conflict. The result is consistent with related studies in the literature (Cohan and Bradbury, 1997; Cramer, 2000; Gottman and Krokoff, 1989; Kurdek, 1995). The negative conflict resolution style is associated with destructive behaviors involving verbal and physical aggression while dealing with conflict. According to Cohan and Bradbury (1997), a destructive conflict resolution style or poor effectiveproblem-solving skills increase sensitivity or vulnerability to stressful life events. According to Greef and De Bruyne (2000), the use of a negative/destructive conflict resolution style between couples causes to reduce marital adjustment and marital satisfaction by reducing the strength and endurance against stress. 
According to the research findings, a negative relationship is found between marital adjustment and disagreement is destructive to a relationship, there are dramatic differences between men's and women's personality and needs, and partners cannot change themselves sub-scales. The result is consistent with related studies in the literature (Bradbury and Fincham, 1993; Eidelson and Epstein, 1982; Haferkamp, 1994; Hamamci, 2005; Möller and Van Der Merwe, 1997). According to Sharp and Ganong (2000), irrational relationship beliefs lead to increased relationship problems and the emergence of maladjustment. Besides, these beliefs are constant, resistant to change, and incompatible with reality. Individuals with these beliefs may possess unhealthy emotions, dysfunctional behaviors, and psychological disorders. These outcomes may lead to a decrease in marital adjustment.

\section{Discussion and interpretation of the findings on the prediction of mar- ital adjustment in the context of personality traits}

As a result of the analysis in the context of predicting the marital adjustment according to the personality traits, it is seen that neuroticism subscale has the power to negatively predict the marital adjustment. In research on romantic relationships and marital relationships, it is demonstrated that the degree of neuroticism is the most consistent and strong personality predictor. A negative relationship is found between the marital adjustment and neuroticism scale (Geist and Gilbert, 1996; Kurdek, 1997; Bouchard, Lussier and Sabourin, 1999). Karney and Bradbury (1995) state that the scale of neuroticism on marital results has a much higher rate of predictive power than other personality traits. In a study conducted by Gattis, Berns, Simpson and Christensen (2004), a relationship is found between the decrease of marital adjustment and a high level of neuroticism, low levels of reconcilability, and a less positive ability to express oneself. Costa and McCrae (1992) assert that neurotic individuals experience negative emotions more often, have poor impulse control, and weak stress management skills. It is indicated that these features have an influence on the decrease in marital adjustment. 
Discussion and interpretation of the findings on the prediction of marital adjustment in the context of beliefs about the relationship

As a result of the analysis in predicting the marital adjustment according to the beliefs about the relationship, it is seen that the partners cannot change themselves, and disagreement is destructive to relationship subscales have the power to predict negatively. The relevant literature shows that having irrational or dysfunctional beliefs about relationships leads to a decrease in marital adjustment (Bradbury and Fincham, 1993; Haferkamp, 1994; Hamamci, 2005; Möller and Van Der Merwe, 1997).

In a study conducted by Hamamc1 (2005), a negative relationship is found between the mind-reading subscale about the relationship beliefs and the marital conflict that women experience. According to DiGuiseppe and Zee (1986), one or two spouses' irrational beliefs related to marital problems are exaggerated, rigid, and illogical. Unrealistic or persistent expectations may lead to frustration and tension with negative interactions, and as a result, adjustment levels of the couples' relationships may decrease.

\section{Discussion and interpretation of the findings on the prediction of mar- ital adjustment in the context of conflict resolution styles}

As a result of the analysis in predicting the marital adjustment according to the conflict resolution styles, it is seen that negative conflict and withdrawal have the power to predict marital adjustment negatively. In contrast, positive conflict has the power to predict marital adjustment positively. It is seen that the results are consistent with the studies in the literature (Cramer, 2000; Dwyer, 2005). Greeff and Bruyne (2000) assert that relationships become stronger when conflicts in marriage are constructively managed, whereas the likelihood of unsatisfied and unhappy relationships increases when conflicts are managed destructively. The use of a negative/destructive conflict resolution style between couples reduces the strength and endurance of defense against stress, decreasing marital adjustment, and satisfaction.

Gottman (1989) claims that the use of the withdrawal conflict resolution style leads to the re-emergence of conflict issues and the formation of 
emotional distance between spouses. It is stated that spouses that use the withdrawal conflict resolution style try not to show their neither positive nor negative emotions avoid discussions and produce less convenient strategies for conflict resolution. It is emphasized that all these behaviors impact the deterioration of marital adjustment in the long term.

According to another result, it is seen that one of the strongest predictive of marital adjustment is positive conflict resolution. Positive conflict resolution style includes dealing with conflict in a constructive way, such as discussing the conflict situation and finding reasonable solutions for couples, and trying to understand the other person (Schrumpf, Crawford, and Bodine, 1997). In this context, it is indicated that these behaviors will increase marital adjustment and marital satisfaction.

It is considered that it would be appropriate to plan experimental research to improve marital relationships. Especially, studies on conflict resolution styles or relationship beliefs may be proposed. It is considered that married individuals could be included in the study as a couple to achieve more comprehensive results. It may be suggested that to explain marriage and family life better, the married couples' children may also be included in the research. Information on variables such as marital adjustment and conflict resolution styles, relationship beliefs or personality traits can be investigated using qualitative methods. In the programs prepared to improve the marital relationship, it is considered that intervention programs to change dysfunctional beliefs about the relationship will be necessary within the framework of a cognitive-behavioral based approach.

\section{References}

Addis, J., and Bernard, M. E. (2002). Marital adjustment and irrational beliefs. Journal of Rational-Emotive and Cognitive-Behavior Therapy, 20(1), 3-13. https://doi.org/10.1023/A:1015199803099

Aluja, A., del Barrio, V., and García, L. F. (2007). Personality, social values, and marital satisfaction as predictors of parents' rearing styles. International Journal of Clinical and Health Psychology, 7(3), 725-737.

Belsky, J., and Kelly, J. J. (1994). The transition to parenthood: how a first child changes a marriage: why some couples grow closer and others apart. New York: Delacoute Press. 
Benet-Martinez, V., and John, O. E. (1998). Los Cinco Grandes Across Cultures and Ethnic Groups: Multitrait Multimethod Analyses of the Big Five in Spanish and English. Journal of Personality and Social Psychology, 75(3), 729-750.

Bouchard, G., Lussier, Y., and Sabourin, S. (1999). Personality and marital adjustment: Utility of the five-factor model of personality. Journal of Marriage and the Family, 61(3), 651-660.

Bradbury, T. N., and Fincham, F. D. (1993). Assessing dysfunctional cognition in marriage: A reconsideration of the relationship Belief inventory. Psychological Assessment, 5(1), 92-101. https://doi.org/10.1037/10403590.5.1.92

Bradbury, T. N., Fincham, F. D., and Beach, S. R. H. (2000). Research on the nature and determinants of marital satisfaction: A decade in review. Journal of Marriage and Family. 62, 964-980. https://doi.org/10.1111/j.1741-3737.2000.00964.x

Burman, B., Margolin, G., and John, R. S. (1993). America's angriest home videos: Behavioral contingencies observed in home reenactments of marital conflict. Journal of Consulting and Clinical Psychology, 61(1), 28-39. https://doi.org/10.1037/0022-006x.61.1.28

Çă̆, P. (2011). Evli bireylerde eş desteği ve evlilik doyumu. Hacettepe Üniversitesi, Sosyal Bilimler Enstitüsü, Ankara.

Caughlin, John P., Huston, T. L., and Houtsve, R. M. (2000). How does personality matter in marriage? An examination of trait anxiety, interpersonal negativity, and marital satisfaction. Journal of Personality and Social Psychology, 78(2), 326-336. https://doi.org/10.1037/00223514.78.2.326

Çınar, L. (2008). Evlilik doyumu: Cinsiyet rolleri ve yardım arama tutumu. Gazi Üniversitesi, Eğitim Bilimleri Enstitüsü, Ankara.

Cohan, C. L., and Bradbury, T. N. (1997). Negative life events, marital interaction, and the longitudinal course of newlywed marriage. Journal of Personality and Social Psychology, 73(1), 114-128. https://doi.org/10.1037/0022-3514.73.1.114

Costa, P. T., and McCrae, R. R. (1992). Normal personality assessment in clinical practice: The neo personality inventory. Psychological Assessment, 4(1), 5-13. https://doi.org/10.1037/1040-3590.4.1.5 
Craig, R. J., and Olson, R. E. (1995). 16 PF profiles and typologies for patients seen in marital therapy. Psychological Reports, 77(1), 187-194. https://doi.org/10.2466/pr0.1995.77.1.187

Cramer, D. (2000). Relationship satisfaction and conflict style in romantic relationships. The Journal of Psychology, 134(3), 337-341. https://doi.org/10.1080/00223980009600873

Debord, J., Romans, J. S. C., and Krieshok, T. (1996). Predicting dyadic adjustment from general and relationship-specific beliefs. Journal of Psychology: Interdisciplinary and Applied, 130(3), 263-280. https://doi.org/10.1080/00223980.1996.9915008

Decuyper, M., De Bolle, M., and De Fruyt, F. (2012). Personality similarity, perceptual accuracy, and relationship satisfaction in dating and married couples. Personal Relationships, 19(1), 128-145. https://doi.org/10.1111/j.1475-6811.2010.01344.x

Demiray, Ö. (2006). Evlilikte uyumun demografik özelliklere göre incelenmesi. Dicle Üniversitesi, Sosyal Bilimler Enstitüsü, Diyarbakır.

Digiuseppe, R., and Zee, C. (1986). A rational-emotive theory of marital dysfunction and marital therapy. Journal of Rational-Emotive Therapy, 4(1), 22-37.

Dökmen, Z. Y., and Tokgöz, Ö. (2002). Cinsiyet, eğitim, cinsiyet rolü ile evlilik doyumu, eşle algilanan benzerlik arasındaki ilişkiler. In XII. Ulusal Psikoloji Kongresi. Ankara: Türk Psikologlar Derneği Yayınları.

Donnellan, M. B., Conger, R. D., and Bryant, C. M. (2004). The Big Five and enduring marriages q. Journal of Research in Personality, 38, 481-504. https://doi.org/10.1016/j.jrp.2004.01.001

Dowd, D. A., Means, M. J., Pope, J. F., and Humphries, J. (2005). Attributions and marital satisfaction: The mediated effects of self-disclosure. Journal of Family and Consumer Sciences, 97(1), 22-26.

Durmuş, E., and Baba, E. (2014). Evli çiftlerin duygusal zeka düzeyleri ile evlilik uyumlarinin karşılaştırılması. Sosyal Bilimler Enstitüsü Dergisi, 23(1), 352-369.

Dwyer, M. (2005). Emotional intelligence and conflict resolution style as predictors of marital satisfaction in the first year of marriage. The Gradute School, University of Kentucky, Lexington, Kentucky, USA. 
Eidelson, R. J., and Epstein, N. (1982). Cognition and relationship maladjustment: Development of a measure of dysfunctional relationship beliefs. Journal of Consulting and Clinical Psychology, 50(5), 715-720. https://doi.org/10.1037/0022-006X.50.5.715

Epstein, N., Pretzer, J. L., and Fleming, B. (1987). The role of cognitive appraisal in self-reports of marital communication. Behavior Therapy, 18(1), 51-69. https://doi.org/10.1016/S0005-7894(87)80051-5

Field, A. (2009). Discopering statistics using SPSS, thrid edition. London: SAGE Publications Ltd.

Fişiloğlu, H., and Demir, A. (2000). Applicability of the Dyadic adjustment scale for measurement of marital quality with Turkish couples. European Journal of Psychological Assessment, 16(3), 214-218.

Fraenkel, J. R., and Wallen, N. E. (1993). How to design and evaluate research in education. (M. Ryan,Ed.) (Eight Edit). New York: McGraw Hill.

Gattis, K. S., Simpson, L. E., Christensen, A., and Berns, S. (2004). Birds of a feather or strange birds? Ties among personality dimensions, similarity, and marital quality. Journal of Family Psychology, 18(4), 564-574. https://doi.org/10.1037/0893-3200.18.4.564

Geist, R., and Gilbert, D. G. (1996). Correlates of expressed and felt emotion during marital conflict: Satisfaction, personality, process, and outcome. Elsevier, 21(1), 49-60.

Gökmen, A. (2001). Evli eşlerin birbirlerine yönelik kontrolcülük ve bağımlılık algilarının evlilik doyumu üzerindeki etkisi. Hacettepe Üniversitesi, Sosyal Bilimler Enstitüsü, Ankara.

Gottman, J. M. (1993). The roles of conflict engagement, escalation, and avoidance in marital interaction: A longitudinal view of five types of couples. Journal of Consulting and Clinical Psychology, 61(1), 6-15.

Gottman, J. M., and Krokoff, L. J. (1989). Marital interaction and satisfaction: A longitudinal view. Journal of Consulting and Clinical Psychology, 57(1), 47-52. https://doi.org/10.1037/0022-006x.57.1.47

Greeff, A. P., and De Bruyne, T. (2000). Conflict management style and marital satisfaction. Journal of Sex \& Marital Therapy, 26(4), 321-334. https://doi.org/10.1080/009262300438724

Haferkamp, C. J. (1994). Dysfunctional beliefs, self-monitoring, and marital conflict. Current Psychology, 13(3), 248-260.

Halford, W. K., and Markman, H. J. (Eds.). (1997). Clinical Handbook of Marriage and Couples Interventions. John Wiley and Sons Inc. 
Hamamci, Z., Kapci, E. G., and Turkcapar, H. (2010). Psychometric properties of the relationship belief inventory in Turkish couples. Anadolu Psikiyatri Dergisi, 11(2), 127-132.

Hamamci, Z. (2005). Dysfunctional relationship beliefs in marital satisfaction and adjustment. Social Behavior and Personality, 33(4), 313-328. https://doi.org/10.1007/s10942-005-0013-y

Hayes, N., and Joseph, S. (2003). Big 5 correlates of three measures of subjective well-being. Personality and Individual Differences, 34(4), 723-727. https://doi.org/10.1016/S0191-8869(02)00057-0

Heavey, C. L., Layne, C., and Christensen, A. (1993). Gender and conflict structure in marital interaction: A replication and extension. Journal of Consulting and Clinical Psychology, 61(1), 16-27. https://doi.org/10.1037//0022-006x.61.1.16

Heller, D., Ilies, R., and Watson, D. (2004). The role of person versus situation in life satisfaction: A critical examination. Psychological Bulletin, 130(4), 574-600. https://doi.org/10.1037/0033-2909.130.4.574

Henri, B., and Jon, H. (2004). Conceptualizing the construct of interpersonal conflict. International Journal of Conflict Management, 15(3), 216-244.

Hortaçsu, N. (2007). Family- versus couple-initiated marriages in Turkey: Similarities and differences over the family life cycle. Asian Journal of Social Psychology, 10(2), 103-116. https://doi.org/10.1111/j.1467839X.2007.00217.x

Hünler, O. S., and Gençöz, T. (2003). Boyun eğici davranışlar ve evlilik doyumu ilişkisi : Algılanan evlilik problemleri çözümünün rolü. Türk Psikoloji Dergisi-TPD, 18(51), 99-108.

Jose, O., and Alfons, V. (2007). Do demographics affect marital satisfaction? Orathinkal Jose \& Vansteenwegen Alfons, 33(1), 73-85. https://doi.org/10.1080/00926230600998573

Karney, B. R., and Bradbury, T. N. (1995). The longitudinal course of marital quality and stability: A review of theory, method, and research. Psychological Bulletin, 118(1), 3-34.

Kelly, E. L., and Conley, J. J. (1987). Personality and compatibility: A prospective analysis of marital stability and marital satisfaction. Journal of Personality and Social Psychology, 52(1), 27-40. https://doi.org/10.1037/0022-3514.52.1.27

Koolaee, A. K., Adibrad, N., and Sedgh, B. S. (2010). The comparison of relationship Beliefs and couples burnout in women who apply for divorce 
and women who want to continue their marital life. Iranian J Psychiatry, 5(1), 35-44.

Kışlak, T. Ş. (1999). Evlilikte uyum ölçeğinin ( EUÖ ) güvenirlik ve geçerlik çalışması. Psikiyatri Psikoloji Psikofarmakoloji Dergisi, 7(1), 50-57.

Kurdek, L. (1997). The link between facets of neuroticism and dimensions of relationship commitment: Evidence from gay, lesbian, and heterosexual couples. Journal of Family Psychology, 11(4), 503-514.

Kurdek, L. A. (1995). Predicting change in marital satisfaction from husbands' and wives' conflict resolution styles. Journal of Marriage and Family, 57(1), 153-164.

Lavee Y. and Ben-Ari, A. (2004). Emotional expressiveness and neuroticism: Do they predict marital quality? Journal of Family Psychology, 18(4), 620-627.

Metz, M. E., and Margretta Dwyer, S. (1993). Relationship conflict management patterns among sex dysfunction, sex offender, and satisfied couples. Journal of Sex and Marital Therapy, 19(2), 104-122. https://doi.org/10.1080/00926239308404894

Möller, A. T., and Van Der Merwe, J. D. (1997). Irrational beliefs, interpersonal perception and marital adjustment. Journal of Rational-Emotive and Cognitive-Behavior Therapy, 15(4), 269-279. https://doi.org/10.1023/A:1025089809243

Özen, A. (2006). Value similarities of wives and husbands and conflict resolution styles of spouses as predictors of marital adjustment. The Graduate School of Social Sciences, Middle East Technical University. http://etd.lib.metu.edu.tr/upload/12607273/index.pdf

Robins, R. W., Caspi, A., and Moffitt, T. E. (2000). Two personalities, one relationship: Both partners' personality traits shape the quality of their relationship. Journal of Personality and Social Psychology, 79(2), 251-259. https://doi.org/10.1037/0022-3514.79.2.251

Rogers, S., and Forces, P. (2000). Have changes in gender relations affected marital quality? Social Forces, 79(2), 731-753.

Russell, R. J. H., and Wells, P. A. (1994). Personality and quality of marriage. British Journal of Psychology, 85(2), 161-168. https://doi.org/10.1111/j.2044-8295.1994.tb02516.x

Schrumpf, F., Crawford, K. D., and Bodine, J. R. (1997). Peer mediation: Conflict resolution in schools: Program guide. Illinois: Research Press. 
Soleimani, S., Sharif, F., Mani, A., and Keshavarzi, S. (2004). The Effect of conflict resolution training on marital satisfaction in couples referring to counseling centers in Shiraz, Southern Iran. International Journal of Community Based Nursing and Midwifery, 1(1), 26-34. http://ijcbnm.sums.ac.ir/index.php/ijcbnm/article/view/20

Sharp, E. A., and Ganong, L. H. (2000). Raising awareness about marital expectations: Are unrealistic beliefs changed by integrative teaching? Family Relations. National Council on Family Relations. https://doi.org/10.1111/j.1741-3729.2000.00071.x

Snyder, D. K., Heyman, R. E., and Haynes, S. N. (2005). Evidence-based approaches to assessing couple distress. Psychological Assessment, 17(3), 288-307. https://doi.org/10.1037/1040-3590.17.3.288

Stanley, S. M., Markman, H. J., and Whitton, S. W. (2002). Communication, conflict, and commitment: Insights on the foundations of relationship success from a national survey. Family Process, 41(4), 659-675. https://doi.org/10.1111/j.1545-5300.2002.00659.x

Sternberg, R., and Hojjat, M. (1997). Satisfaction in close relationships. New York: Guilford Press.

Sümer, N., Lajunen, T., and Özkan, T. (2005). Big five personality traits as the distal predictors of road accident. Traffic and Transport Psychology, 18, 215-227.

Tobin, R. M., Graziano, W. G., Vanman, E. J., and Tassinary, L. G. (2000). Personality, emotional experience, and efforts to control emotions. Journal of Personality and Social Psychology, 79(4), 656-669. https://doi.org/10.1037/0022-3514.79.4.656

Twenge, J. M., Campbell, W. K., and Foster, C. A. (2003, August). Parenthood and Marital Satisfaction: A Meta-Analytic Review. Journal of Marriage and Family, 65, 574-583. https://doi.org/10.1111/j.17413737.2003.00574.x

Vaillant, C. O., and Vaillant, G. E. (1993). Is the U-curve of marital satisfaction an illusion? A 40-year study of marriage. Journal of Marriage and the Family, 55(23), 230-239.

Watson, D., Hubbard, B., and Wiese, D. (2000). General traits of personality and affectivity as predictors of satisfaction in intimate relationships: Evidence from self- and partner-ratings. Journal of Personality, 68(3), 413-449. https://doi.org/10.1111/1467-6494.00102 
Zeytinoğlu, E. (2013). Evli bireylerin benlik saygısı, kıskançlık düzeyi, evlilikteki çatışmalar ve evlilik doyumu arasındaki ilişkilerin incelenmesi. Dokuz Eylül Üniversitesi, Eğitim Bilimleri Enstitüsü, İzmir.

Zoby, M. (2005). The association between personality and marital and relationship outcome. Regent University, Virginia Beach, Virginia. https://search.proquest.com/docview/305379290?pqorigsite $=$ gscholar\&fromopenview $=$ true

\section{Kaynakça Bilgisi / Citation Information}

Çakmak Tolan, Ö. ve Kılıç, M. (2021). Prediction of marital adjustment in the context of personality traits, relationship beliefs and conflict resolution styles (sample of Diyarbakır). OPUS-International Journal of Society Researches, 18(40), 2056-2084. DOI: 10.26466/opus.854688. 